\title{
Strategi Promosi Digital Online Shop Aisar.Scarf dalam Meningkatkan Penjualan Produk Hijab
}

\author{
Muhammad Andre Alkahfi' ${ }^{1}$, Putri Ayuni' ${ }^{2}$, Fitri Rorizki ${ }^{3}$, \\ Maryam Batubara ${ }^{4}$, Purnama Silalahi ${ }^{5}$ \\ Asuransi Syariah, Fakultas Ekonomi dan Bisnis Islam \\ Universitas Islam Negeri Sumatera Utara, Medan, Indonesia \\ muhammad.andre.alkahfi@gmail.com¹, pa685160@gmail.com², ftrirryzki@gmail.com³, \\ maryam.batubara@uinsu.ac.id ${ }^{4}$, purnamaramadani@uinsu.ac.id ${ }^{5}$
}

\begin{abstract}
Currently, many fashion stores use the Internet for convenience and time savings. Aisar.Scarf are one of the fashion manufacturers who employ internet marketing and are the type of goods offered in the hijab market. This article analyzes a business in the hijab industry that markets its products through online marketing and aims to find out used the marketing strategy as well as product quality, price and service at this online store. This research is a survey research with a qualitative approach, where data is obtained through observation of the online media used, messages conveyed and forms of marketing, as well as conducting special interviews with the owner/owner of Aisar.Scarf and also by several people who are non-consumers of Aisar.Scarf with chat or question and answer. The conclusion from this discussion can be interpreted that the marketing strategy used in Aisar.Scarf only uses one marketing method, namely the online marketing approach. And also the product quality, price and service are quite good.
\end{abstract}

Keywords: Promotion, Strategy, Digital, Hijab.

\section{ABSTRAK}

Saat ini penjualan fashion untuk memudahan bertransaksi serta menghemat waktu banyak yang menggunakan internet. Aisar.Scarf merupakan produk fashion yang menggunakan internet marketing dan jenis produk yang ditawarkan adalah hijab. Artikel ini menganalisis sebuah usaha di industri hijab yang memasarkan produknya melalui pemasaran online serta bertujuan untuk memahami digital marketing yang sedang digunakan serta kualitas produk, harga dan pelayanan di toko online ini. Penelitian kali ini adalah penelitian survei menggunakan pendekatan kualitatif, dimana data diperoleh melalui observasi terhadap media online yang digunakan, pesan yang disampaikan dan bentuk pemasaran, serta melakukan wawancara khusus dengan owner/pemilik Aisar.Scarft dan juga oleh beberapa orang yang merupakan nonkonsumen dari Aisar.Scarf dengan chat atau tanya jawab. Kesimpulan dari pembahasan ini dapat diartikan bahwa strategi pemasaran yang digunakan dalam Aisar.Scarf hanya menggunakan satu metode pemasaran, yaitu pendekatan pemasaran online. Dan juga Kualitas produk, harga dan pelayanan cukup baik.

Katakunci: Promosi, Strategi, Digital, Hijab. 


\section{Vol 3 No 3 (2022) 466-483 P-ISSN 2620-295 E-ISSN 2747-0490 DOI:_1047467/elmal.v3i3.930}

\section{PENDAHULUAN}

Teknologi digital membawa perubahan besar di dunia, dan lahirnya banyak teknologi baru, terutama di Internet. Internet adalah alat komunikasi yang populer. Hal tersebut pula yang melatarbelakangi dilakukannya modifikasi sistem komunikasi yang ada dan dilakukan secara serba digital dan online. Hermawan,Kartajaya (2009) menyebutkan bahwa Internet adalah solusi yang layak untuk komunikasi antar konsumen. Hal tersebut dikarenakan meningkatnya jumlah pengguna internet dan akses tak terbatas ke perangkat secara umum. Sekarang, penggunaan Internet tidak hanya dapat dilakukan oleh komputer tetapi juga oleh telepon seluler, demikian para peselancar internet (Netizen) yang Jumlahnya bertambah.

Berdasarkan data dari datareportal.com pada Januari 2021, pengguna internet Indonesia menduduki peringkat ketiga dunia dengan total 202,6 juta orang. Jumlah dari pengguna atau pemakai internet di Indonesia terus bertambah 27 juta $(+16 \%)$ dari tahun 2020 sampai 2021 atau 73,7\% dari total populasi masyarakat keseluruhan. Data dari dukcapil.kemendagri.go.id, populasi Indonesia berjumlah 272.229.372 jiwa juta orang. Dengan demikian data di atas menunjukkan bahwa $70-75 \%$ dari total masyarakat Indonesia merupakan pengguna internet.

Saat ini di Era digital membuat banyak orang memakai media internet (sosial media) untuk mengembangkan bisnis mereka. Perusahaan yang tidak dapat beradaptasi dengan perkembangan zaman tidak membuat mereka kompetitif. Banyak konsumen atau masyarakat Indonesia yang teredukasi secara digital. Hal ini terlihat dari semakin banyaknya pengguna jejaring sosial.

Facebook adalah jejaring sosial terpopuler kedua dengan pengguna aktif. Instagram adalah afiliasi terbesar ketiga Facebook. Inilah yang muncul dari survei yang telah dilaksanakan oleh JAKPAT Mobile Survey dengan topik tren media sosial Indonesia 2021. Facebook adalah mediia sosial kedua yang paling banyak digunakan oleh orang Indonesia. Pertumbuhan eksplosif pengguna Facebook sserta semakin melebarnya penggunaan internet di Indonesia telah memberikan peluang dan pemasaran bagi banyak orang yang kemudian dikenal sebagai social media promosi. Ini karena Facebook dan Instagram memiliki profil lengkap seperti preferensi pengguna, usia, populasi, wilayah, suka, tidak suka, dll. Pendapatan yang didapatkan dari aktivitas internet sangat tinggi. Pemakaian internet pada suatu perusahaan berubah menjadi status alat pertukaran data ellektronik menjadi alat untuk menerapkan strategi komersial seperti: penjualan, layanan pelanggan, bisnis dengan kualitas yang baik.

Satu langkah awal dalam menghadirkan produk kepada konsumen adalah dengan melakukan komunikasi pemasaran, dan hal tersebut akan menjadii sangat bagus karena akan mempengaruhi laba yang bisa didapatkan oleh si penjual. Sama hal- 


\section{Vol 3 No 3 (2022) 466-483 P-ISSN 2620-295 E-ISSN 2747-0490 DOI:_1047467/elmal.v3i3.930}

nya yang kita lihat, Internet saat ini adalah media promosi yang cocok untuk lebih dekat dengan publik. Banyak sekali serta meluasnya penjualan produk dari internet yang ditawarkan oleh pelaku bisniis online, baik nasional atau internasional, termurah sampai yang termahal. Bisnis online juga memenuhi berbagai kebutuhan masyarakat, seperti pakaian, elektronik, tas, sepatu, dan lain-lain yang tersedia bagi mereka yang ingin membeli dengan cepat dan sederhana tanpa meninggalkan rumah.

Sistem bisnis online lebih mudah diterapkan dan tidak memerlukan modal/biaya yang besar, baik di awal maupun selama pengoperasiannya. Hanya perlu koneksi iinternet lancar merupakan modal utama untuk mengembangkan bisnis secara online. Sifat pasar online yang sangat dinamis dan memerlukan perubahan yang cepat, memerlukan respon dan langkah yang tepat agar suatu produk atau jasa dapat bertahan dan mengalahkan persaingan. Komunikasi pemasaran menjadi alat yang penting dan mulai diperhatikan secara serius dalam sistem pemasaran online untuk mengatasi tantangan tersebut, dimana lebih peting cara penyampaian kepada pelanggan.

Saat ini di Indonesia fashion hijab bukan cuma menjadi trend fashion semata, tetapi juga trend yang ada di dalam dan luar negeri. Karena banyak sekali desainer hijab Indonesia yang terus menerus memproduksi trend fashion hijab terbaru. Menurut Uwais Saida, Kementerian Perindustrian serta Diirektur Jenderal Industri Kecil dan Menengah (IKM), sekitar lebih dari 20 juta orang Indonesia mengenakan hijab. Hal tersebut juga beriringan dengan meningkatnya industri busana muslim sebesar $7 \%$ per tahunnya. Tidak heran Asosiasi Desainer Pengusaha Mode Indonesia (APPMI) berkeinginan dapat mengembangkan fashion muslim Indonesia tidak hanya secara nasional, tetapi juga internasional. (Kompasiana, Ramadhani, dikutip 12/12/2021).

Jilbab merupakan kebutuhan primer bagi umat Islam untuk menutup aurat, masyarakat tidak hanya menganggap memakai jilbab sebagai alat penutup aurat, tetapi juga melihat pola dan kenyamanan dari produk yang dibeli. Nilai kepuasan merupakan faktor penting dalam pembelian suatu produk. Aisar.Scarf telah muncul sebagai produsen hijab dengan berbagai jenis yang dapat menjadi jalan bagi masyarakat untuk memenuhi kebutuhan mereka akan hijab yang syar'i, instan,dan trendy.

\section{TINJAUAN LITERATUR}

Pemasaran digital awalnya diperkenalkan pada tahun 1990 dan menjadi strategi utama pada tahun 2014 yang banyak digunakan dalam bisnis. Ada beberapa tahapan pemasaran digital yang merupakan salah satu bentuk penerapan atau penggunaan teknologi informasi dalam proses pemasaran berlangsung yaitu sebagai berikut (Ryan, 2014: 4):

A. Muncul dan mulai digunakannya teknologi baru. 


\section{Vol 3 No 3 (2022) 466-483 P-ISSN 2620-295 E-ISSN 2747-0490 DOI:_1047467/elmal.v3i3.930}

B. Teknologi mulai dikenal dan diprioritaskan dalam dunia pemasaran

C. Pemasar yang inovatif mengeksplorasi dan memajukan untuk meningkatkan fungsionalitas atau kegunaan teknologi untuk mencapai tujuan pemasaran yang ditargetkan.

D. Teknologi telah menjadi strategi utama dan telah diadopsi sebagai standar praktik pemasaran.

Tahap ini menunjukkan bagaimana teknologi membantu dalam pengembangan gagasan pemasaran digital, namun demikian, teknologi hanyalah alat pemasaran apakah itu alat komunikasi yang dapat meningkatkan efektivitas interaksi manusia, atau dalam hal ini, antar manusia? (Ryan, 2014: 4) Pemasar dan pasar (target market). Pemasaran digital bukanlah konsep yang berpusat pada teknologi, melainkan orang (pemasar), yaitu bagaimana orang (pemasar) dipersepsikan dan bagaimana teknologi digunakan untuk membangun hubungan dengan orang lain (pelanggan) guna menghasilkan penjualan yang meningkat (Ryan, 2014:12).

\section{Definisi Pemasaran}

Menurut American Marketing Association (AMA), dikutip oleh Kotler dan Keller (2016:27), pemasaran adalah fungsi organisasi dan serangkaian proses yang digunakan untuk membangun, mengomunikasikan, dan mengelola hubungan dengan konsumen, organisasi dan operasinya menguntungkan pemegang bisnis. Oleh karena itu, praktik pemasaran bertujuan sebagai gambaran terhadap konsumen tentang bagaimana jasa dan produk yang ditawarkan di pasar. Dengan pemikiran ini, pemasaran adalah kegiatan utama dalam memasarkan produk dan layanan kepada bisnis

\section{Digital Marketing}

Sekarang, Teknologi informasi sudah menaklukkan pasar utama dan berkembang sebagai gelombang teknologi baru. Menurut Kotler, teknologi New Wave merupakan teknologi yang memungkinkan terjadinya komunikasi dan interaksi antar individu maupun kelompok. Pemasaran digital adalah metode pemasaran yang menggunakan "saluran penjualan digital" untuk akses yang efektif, pribadi, dan menguntungkan kepada konsumen (Satio, 2009). Kegiatan pemasaran yang ekstensif dengan komputer, baik melalui presentasi produk, pembayaran dan pengiriman.

\section{Definisi Strategi Pemasaran}

Strategi pemasaran merupakan salah satu cara perencanaan suatu usaha demi mendapatkan hasil yang terbaik. Kisaran strategi pemasaran sangat luas dan mencakup strategi anti persaingan, strategi produk, strategi penetapan harga, strategi pelokalan, dan strategi periklanan. Menurut Tull dan Kahle, strategi pemasaran merupakan alat penting dalam mencapai tujuan perusahaan dengan mengembangkan daya saing yang berkelanjutan melalui masuknya pasar. Oleh karena itu, strategi pemasaran adalah proses dinamis dan inventif dari perusahaan pemasaran yang mengembangkan dan memberikan produk dan layanan kepada pelanggan untuk mencapai tujuan tertentu, 


\section{Vol 3 No 3 (2022) 466-483 P-ISSN 2620-295 E-ISSN 2747-0490 DOI:_1047467/elmal.v3i3.930}

dengan semua risiko yang menyertainya. Taktik lama dan baru, seperti pemasaran digital yang digunakan..

\section{Strategi Pemasaran}

Terdapat dua kata dalam "strategi pemasaran", yaitu kata "strategi dan kata "pemasaran". Pengertian strategi menurut Glueck, dikutip lagi dalam R. A. Supriyono (1990:10), Merupakan respon yang berkesinambungan/adaptif terhadap peluang dan ancaman eksternal serta kekuatan dan kelemahan internal yang dapat mempengaruhi bisnis. Pemasaran sekarang merupakan proses sosial di mana individu dan organisasi mencapai apa yang mereka inginkan dan butuhkan (Philip Kotler, 1991: 20). Dari penjelasan di atas, strategi pemasaran merupakan proses yang diperlukan dan metode dan strategi perlu terus diperbarui sesuai dengan kebutuhan sosial yang ada. Tanpa adaptasi yang memadai dan efektif terhadap lingkungan baru, maka akan terganggu oleh perusahaan lain, terutama yang memiliki kegiatan manufaktur serupa.

\section{METODE PENELITIAN}

Dalam penelitian ini, peneliti menggunakan tipe kualitatif. Penelitian kualitatif dilakukan dengan tujuan untuk menjelaskan secara detail fenomena melalui pengumpulan data yang mendalam (Kriyantono, 2009). (Moleong, 2006) bahwa pendekatan kualitatif tidak mengumpulkan data berupa angka-angka dan oleh karena itu tujuan penelitian kualitatif adalah untuk memberikan gambaran yang komprehensif, akurat, dan lengkap tentang realitas empiris di balik fenomena tersebut.

Dalam penelitian kualitatif, pengumpulan data sangatlah penting. Penelitian data kualitatif, tidak seperti penelitian kuantitatif, tidak melakukan mengumpulan dataa melalui alat yang dirancang untuk mengukur variabel penelitian. Tetapi mengumpulkan data penelitian kualitatif berarti peneliti secara simbolis berinteraksi dengan narasumber (Iiskandar, 2009).

Data dalam penelitian kualitatif dapat dikumpulkan oleh peneliti dengan menggunakan berbagai teknik pengumpulan data. Pengumpulan data dalam penelitian Strategi Promosi Digital Aisar.Scarf terbagi menjadi dua jenis metode, yaitu:

A. Pengamatan (Observasi)

Observasi atau bisa disebut pengamatan adalah teknik pengumpulan data dengan mengamati sesuatu atau suatu peristiwa. Observasi memiliki tujuan supaya peneliti merasakan dan memahami suatu objek atau peristiwa berdasarkan pengetahuan dan gagasan yang sudah ada sebelumnya, serta memperoleh keterangan yang diperlukan untuk meneruskan penelitian. 


\section{Vol 3 No 3 (2022) 466-483 P-ISSN 2620-295 E-ISSN 2747-0490 DOI:_1047467/elmal.v3i3.930}

Penelitian ini menggunakan observasi tidak terstruktur, teknik yang biasa digunakan dalam penelitian kualitatif.

B. Wawancara.

Wawancara dilakukan sebagai bagian dari observasi partisipatif dimana peneliti terlibat penuh dalam penyusunan penelitian, khususnya topik peneliitian (Iskandar, 2009). Mc. Milan \& Schumacher (2001) dalam Satori \& Komariah (2010) wawancara merupakan pertanyaan terbuka dan jawaban untuk memperoleh data tentang niat partisipan tentang bagaimana menggambarkan peristiwa atau fenomena yang terkait dengan setting penelitian.

Dengan cara chat/pesan pribadi antara peneliti sebagai pewawancara dengan informan. Informan yang akan peneliti wawancara adalah Yulia Dwi Erinda, selaku owner dari subjek yang diteliti, yaitu Aisar.Scarf. Dalam penelitian ini, wawancara dengan berbagai pertanyaan tentang topik penelitian dilakukan melalui jejaring sosial yaitu Instagram.

\section{HASIL PENELITIAN DAN PEMBAHASAN}

Aisar.Scarf merupakan produsen fashion hijab yang mengutamakan kualitas, serta brand hijab yang menggunakan jalur online untuk memasarkan produknya. Aisar.Scarf didirikan oleh seorang perempuan asal Medan, Sumatera Utara, Silvi Khairiyah, pada Agustus 2018. Bisnis online ini dimulai dari dirinya sendiri. Kemudian Aisar.Scarf berkembang cukup baik dan mulai mempekerjakan dua orang untuk membantunya mengembangkan bisnis hijabnya.

Modal awal yang dikeluarkan oleh Aisar.Scarf saat mulai memproduksi hijab adalah Rp 2.000.000. Sistem pembayaran yang dilakukan oleh Aisar.Scarf adalah pembayaran penuh. Ketika konsumen telah memutuskan model hijab yang akan dibeli, pembayaran diselesaikan terlebih dahulu. Anda dapat membayar tunai atau melalui transfer bank. Bisnis yang awalnya iseng ini kini berkembang pesat dan diminati banyak orang. Hal ini terlihat dari pengikut Instagram Aisar.Scarf sebanyak 2.385 followers dan ecommerce Shopee sebanyak 765 serta ranting/peniliaian sebanyak 4,9.

Berdasarkan penemuan penelitian, pengamatan dilakukan dengan mengamati empat jenis akun pemasaran digital Aisar.Scarf adalah ; Instagram, Shopee, Tokopedia, dan Tiktok. Di bawah ini adalah gambar dari empat jenis akun media sosial dan ecommerce dengan screenshot menggunakan komputer : 


\section{El-Mäl| | Jurral Kalian theonomi \& Bisisis stam}

Vol 3 No 3 (2022) 466-483 P-ISSN 2620-295 E-ISSN 2747-0490 DOI:_1047467/elmal.v3i3.930
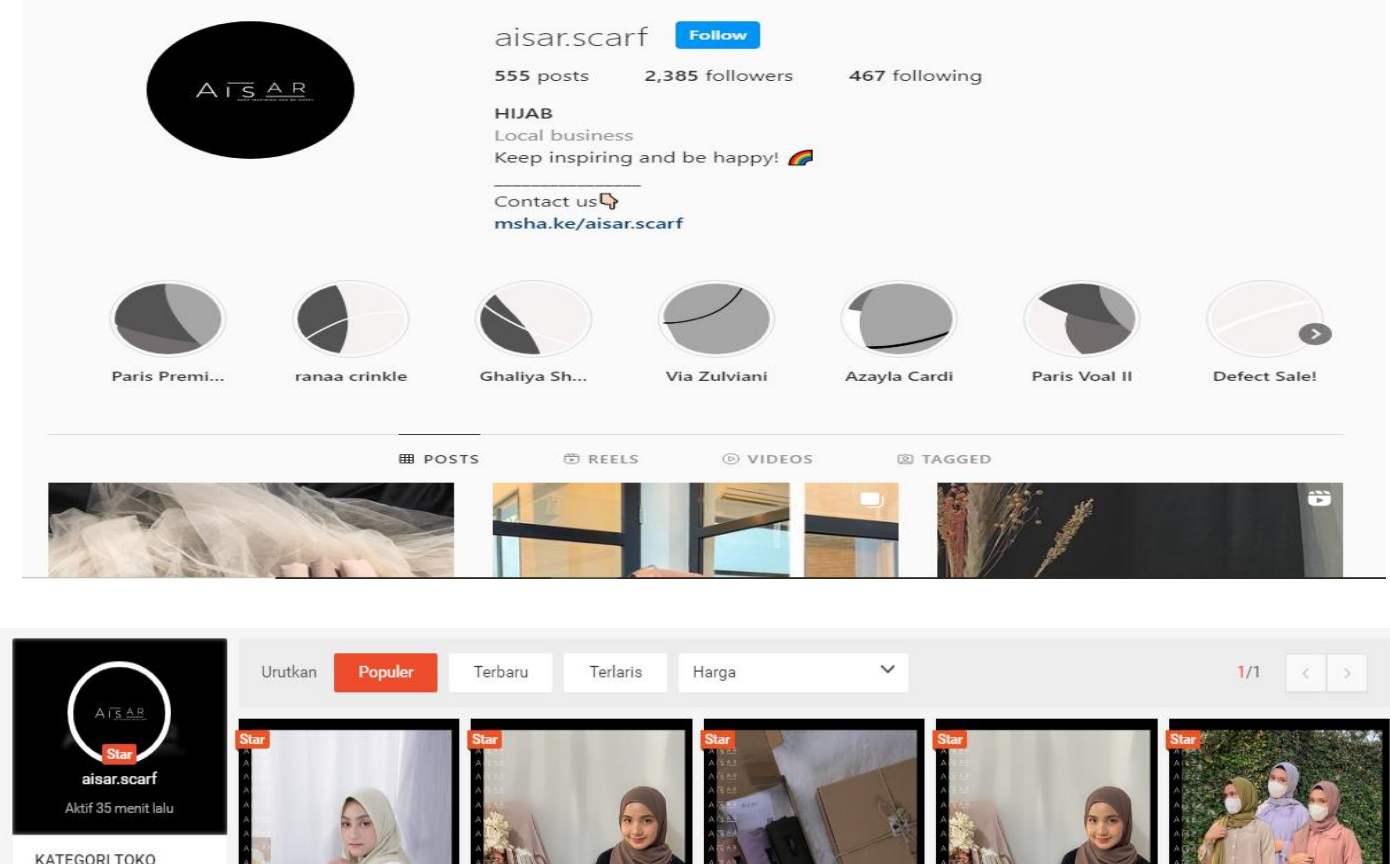

Hijab Segi Empat

Pashmina

Pakaian Wanita

Perlengkapan Rumah

outerwear

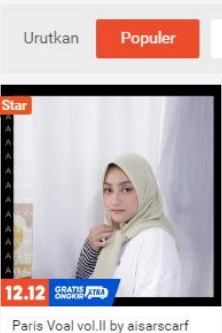

Paris Voal vol.ll by aisarscarf

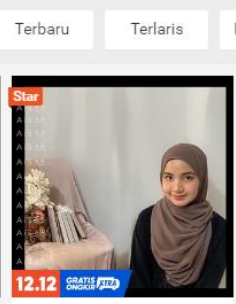

Ghaliya Shawl by aisarscarf
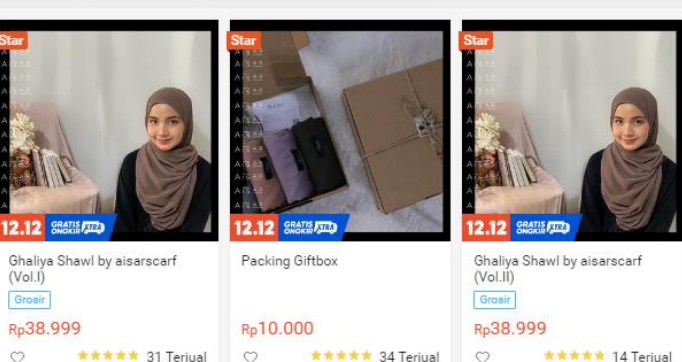

Packing Giftbox

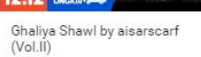

Rp 10.000

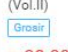

Rp38.999

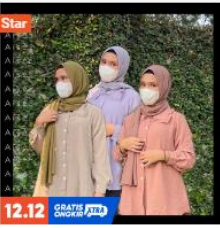

Ranaa Crinkle Shirt

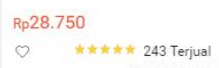

KOTA MEDAN
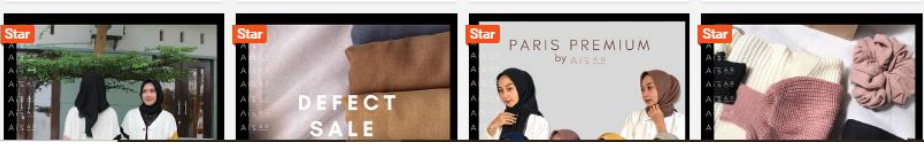

Rp 105.000

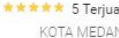

KOTA MEDAN

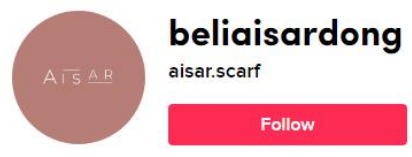

9 Following 942 Followers 22K Likes

Get yours on our instagram @aisar.scarf

O msha.ke/aisar.scarf/

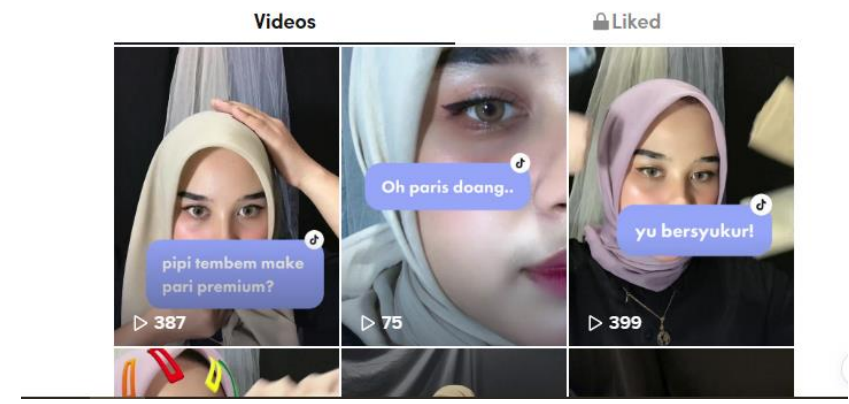

Gambar 1 : Akun Aisar.Scarf (Instagram,Shopee,dan Tiktok) 


\section{Vol 3 No 3 (2022) 466-483 P-ISSN 2620-295 E-ISSN 2747-0490 DOI:_1047467/elmal.v3i3.930}

Media sosial Aisar.Scarf yang dapat dilakukan observasi terdiri dari instagram dan Tiktok, juga ecommerce yaitu Shopee dan Tokopedia. Akun media sosial Aisar.scarf dapat dikunjungi dengan nama @aisar.scarf kecuali untuk Tiktok lihat (Gambar 1). Seperti jejaring sosial yang lainnya, Instagram digunakan melalui akun pribadi sebagai akun resmi.

Seiring dengan perkembangan internet, sekarang lebih mudah bagi pengguna untuk mendapatkan informasi yang banyak dan luas. Ini adalah peluang bagus bagi pemilik bisnis untuk menggunakannya sebagai alat pemasaran. Penggunaannya bisa diterapkan dengan menyebarkan informasi melalui berbagai sarana di Internet. Sama seperti Aisar. Scarf merupakan brand hijab dengan kegiatan pemasaran di berbagai media internet online. Jejaring sosial dan perdagangan internet digunakan untuk pemasaran media, khususnya; Instagram, Tiktok, Shopee, dan Tokopedia.

Menurut penilaian dari beberapa akun digital marketing, jejaring sosial Instagram digunakan oleh Aisar.Scarf sebagai media pemasaran. Hal ini terlihat dari aktivitas Instagram Aisar.Scarf yang antara lain memposting foto dan video ke akun serta Instagram Stories. Dalam penelitian ini, data diperiksa secara deskriptif dengan menggunakan metodologi analisis data seperti observasi, wawancara, dan dokumentasi. Wawancara dilakukan dengan dua pengguna aktif internet, pengguna hijab modern (non-Konsumen non-Aisar.Scarf.) dan pengguna hijab modern (non-Konsumen Aisar.Scarf).

Penelitian dilakukan melalui wawancara mendalam menggunakan percakapan pribadi di platform media sosial WhatsApp dan Instagram, wawancara dilakukan secara sistematis, dengan pertanyaan yang telah ditulis sebelumnya. Hasil wawancara menunjukkan perbedaan pandangan tentang pengertian dalam penggunaan internet dan jejaring sosial sesuai dengan kategorinya masing-masing. Melalui ini, berbagai kategori pengguna seperti pengguna internet aktif Muslim memiliki pengetahuan yang berbeda tentang Aisar.Scarf. sebagai brand hijab yang dipromosikan melalui digital marketing yaitu jejaring sosial dan e-commerce, pertanyaan-pertanyaan yang telah diberikan dengan jawaban sebagai berikut:

\section{Pengguna hijab modern : Dinda Oktaviani (non-konsumen Aisar.Scarf)}

"Hampir semua orang di dunia mengenal apa itu internet. Baik anak-anak hingga orang dewasa pasti sudah tidak asing lagi dengan istilah tersebut. Bahkan kini hampir semua aspek dalam kehidupan manusia mengandalkan teknologi internet. Sehingga sudah bukan rahasia lagi untuk mencari informasi pengertian internet dan solusi hanya dengan mengandalkan internet. Dan dalam kehidupan sehari-hari internet itu berfungsi sebagai fungsi memudahkan kita dalam mengakases informasi maupun komunikasi kita kepada siapapun dalam hal apapun dan media sosial itu sendiri sangat dibutuhkan 


\section{Vol 3 No 3 (2022) 466-483 P-ISSN 2620-295 E-ISSN 2747-0490 DOI:_1047467/elmal.v3i3.930}

dimasa pandemi ini media internet itu sangat trend . karena melalui internet kita bisa melakukan apapun seperti belanja online, belajar online, bekerja pun secara online".

Sebagai pengguna hijab modern, pengguna non konsumen mengetahui internet adalah pada umumnya semua aspek kehidupan mengandalkan teknologi. Dia memanfaatkan internet untuk mencari informasi dan sebagai solusi dalam mengakses informasi apapun. Ia menggunakan internet sebagai media sosial yang dapat terhubung dengan siapa saja, termasuk keluarganya, sekaligus sebagai tempat menemukan dirinya melalui media sosial dan berbelanja segala kebutuhan. Namun pengguna tersebut tidak mengetahui Aisar.Scarf sebagai brand hijab modern yang dipasarkan melalui digital marketing.

"Media sosial seperti menjadi sesuatu yang wajib dimiliki oleh setiap orang. Hal ini bisa kita lihat dari banyaknya akun-akun di media sosial seperti Instagram, Twitter, atau Facebook. Dengan banyaknya pengguna di media sosial, maka kita tidak heran jika platform ini sering dimanfaatkan dalam bidang bisnis. Media sosial umumnya dirancang untuk memudahkan seseorang dalam bersosialisasi dan berkomunikasi dengan orang lain. Platform ini juga bermanfaat untuk menjalin silaturahmi, menambah relasi, dan bahkan saat ini juga banyak yang menjadikannya sebagai wadah untuk menunjukkan karya mereka"

Menurutnya media sosial adalah suatu hal yang wajib dimiliki oleh semua orang apalagi dalam hal mengembangkan bisnis. Baginya media sosial dapat memudahkan siapapun dalam bersosialisasi dan berkomunikasi serta tak luput pula bahwa adanya media sosial baginya untuk mengembangkan bakat/karya yang dimiliki siapapun.

"Sebelumnya saya kurang tau apa itu aisar.scarf menurut pendapat saya itu sejenis tokoyang menyediakan segala jenis hijab Muslimah. Saya juga kurang tau tentang aisar.scarf baru tau karna diwawancarai . Jadi sebelumnya saya juga belum pernah buka Website dan Juga media sosial nya aisar.scarf, kalo boleh kamu kasi tau nama media sosialnya siapa tau saya tertarik melihat produk-produk yang dijual".

Seperti yang disebutkan oleh narasumber pertama yaitu pengguna hijab modern yang merupakan sasaran pasar Aisar.Scarf, ia mengatakan tidak mengetahui apa itu Aisa.Scarf dan ia juga berpendapat bahwa itu merupakan toko hijab muslimah, dia juga baru mengetahui nama Aisar.Scarf dikarenakan diwawancari ini. Ia juga berinsiatif akan melihat media sosial maupun ecommerce dari Aisar.Scarf jikalau target pasar Aisar.Scarf bisa menarik minat narasumber diatas maka strategi promosi yang dilakukan oleh Aisar.Scarf terbilang bagus.

\section{Pengguna hijab modern: Cantika Florentina (non-konsumen Aisar.Scarf)}




\section{Vol 3 No 3 (2022) 466-483 P-ISSN 2620-295 E-ISSN 2747-0490 DOI:_1047467/elmal.v3i3.930}

"internet itu suatu alat komunikasi yang selalu di pakai Masyarakat untuk menggali informasi. Saya mengenal internet sejak terkenalnya jejaring sosial Facebook. adanya internet ini menjadikan masyarakat dapat dengan mudah menggali informasi penting lainnya"

Sebagai pengguna hijab modern, pengguna non konsumen mengetahui internet adalah suatu alat komunikasi yang di pakai masyarakat untuk menggali semua informasi. Namun ia mengatakan mengenal intenet sejak terkenalnya jejaring sosial yang bernama Facebook.

"Media sosial adalah sebuah media daring yang digunakan satu sama lain yang para penggunanya bisa dengan mudah berpartisipasi, berinteraksi, berbagi, dan menciptakan isi blog, jejaring sosial, wiki, forum dan dunia virtual seperti situs scoutex tanpa dibatasi oleh ruang dan waktu"

Menurutnya, dengan media sosial pengguna dapat dengan cepat berpartisipasi, berbagi, konten blog, dan lainnya di media sosial, yang merupakan media bersama., tanpa dibatasi oleh waktu atau geografi, sehingga Internet memiliki banyak keunggulan..

"Saya kurang tau tentang online shop tersebut. Tetapi karena kamu jelaskan kalau itu toko online shop yang menjual Hijab. Menurut saya itu bagus ya, karena adanya toko hijab seperti itu danapalagi hijabnya yang berkualitas dan mengikuti trend masa kini, dari segi motif ataupun bentuk, Pasti menarik minat Orang untuk membeli hijab dari toko online shop tersebut."

Seperti yang di sebutkan oleh pengguna hijab modern, adanya toko (online shop) hijab seperti aisar.scarf jika kualitasnya bahan dan mengikuti trend masa kini dari sgi motif ataupun bentuk, akan menumbuhkan minat customer untuk membeli hijab dari took online tersebut.

Maka jika dilihat dari hasil wawancara antara 2 narasumber diatas mereka tak satu pun yang tau tentang online shop Aisar.Scarf, seperti yang kita ketahui bahwa internet itu sangat luas dan online shop yang ada di sosial media seperti instagram itu banyak sekali, jadi mungkin strategi promosi yang dilakukan oleh Aisar.Scarf kurang sampai pada semua kalangan masyarakat.

Saat ini, Instagram Aisar.Scarf hanya berfungsi sebagai katalog untuk pelanggan dan konsumen. Hal ini dibuktikan dengan semakin banyaknya pelanggan serta peminat yang berkomunikasi serta menanyakan tentang unggahan terbaru melalui pesan pribadi Instagram dan pesan melalui chat shopee maupun tokopedia, setiap hari ketika ada postingan terbaru di Instagram. 


\section{Vol 3 No 3 (2022) 466-483 P-ISSN 2620-295 E-ISSN 2747-0490 DOI:_1047467/elmal.v3i3.930}

Menurut Kotler dan Armstrong (1996), pemasaran dilakukan melalui berbagai media periklanan yang dapat berinteraksi langsung dengan konsumen. Hal ini dilakukan dengan tujuan agar konsumen dapat langsung merespon apa yang ditawarkan. Ada empat jenis utama komunikasi pemasaran langsung: pemasaran pesanan dan katalog, pemasaran jarak jauh, pemasaran jarak jauh, dan belanja online. Namun Kotler dan Armstrong pada tahun 1996 berpendapat bahwa pemasaran langsung melalui media online telah gagal dalam beberapa sistem. Hal ini disebabkan kurangnya klien atau masih sedikitnya jumlah pengguna. Meskipun relatif sedikit para konsumen yang memakai sistem elektronik ini, jumlahnya diperkirakan akan meningkat di tahun-tahun mendatang.

Saat ini pemasaran langsung melalui pemasaran digital telah banyak digunakan oleh berbagai pengusaha atau perusahaan. Buktinya adalah perkembangan teknologi di komputer dan smartphone yang semakin banyak digunakan oleh lebih banyak pengguna, menjadikannya peluang besar bagi pengusaha atau perusahaan. Melihat perkembangan tersebut, Aisar.Scarf. Sebagai brand hijab, mampu memanfaatkan peluang ini dengan memanfaatkan teknologi melalui direct marketing atau digital marketing yang ada.

Pemasaran dengan pemasaran digital memiliki banyak keuntungan yang dapat dimanfaatkan oleh pelanggan dan konsumen, mulai dari riset produk hingga pemilihan produk hingga pembelian produk (penawaran) dan pengiriman produk. Kegiatan ini dapat dengan mudah dilakukan dengan smartphone atau komputer melalui email dan internet. Hal ini tentu saja dapat mengurangi biaya iklan perusahaan pemasaran.

Melalui perkembangan teknologi internet, media sosial sebagai salah satu salah satu perkembangannya telah membawa banyak manfaat bagi penggunanya. Menurut hasil penelitian, Instagram saat ini menjadi salah satu jejaring sosial yang paling banyak digunakan oleh berbagai pelapor dalam dua kategori wanita Muslim.

Selain untuk bersosialisasi, Instagram digunakan untuk menggali informasi atau fenomena terkini yang terjadi dalam kehidupan sosial saat ini. Seperti yang dilakukan Aisar.Scarf untuk setiap desain produk serta konten dalam pemasaran melalui sosial media Instagram yang selalu memberikan nuansa terbaru. Selain itu, berbagai layanan yang ditawarkan dan kemudahan penggunaan aplikasi ini menjadi salah satu daya tarik bagi pengguna internet aktif yang menggunakannya. Ini juga salah satu penyebab bertambahnya jumlah followers (pengikut) di akun Instagram Aisar.Scarf, jadi Meningkatkan jumlah konsumen yang bertransaksi online.

Menurut Kotler \& Armstrong (2008), ), mereka menyebutkan bagaimana perusahaan menggunakan pemasaran internet untuk menjual produk dan layanan mereka dan membangun koneksi konsumen online. Selanjutnya, pemasaran online 


\section{Vol 3 No 3 (2022) 466-483 P-ISSN 2620-295 E-ISSN 2747-0490 DOI:_1047467/elmal.v3i3.930}

harus diutamakan daripada aplikasi kreatif dan teknis seperti desain, periklanan, pengembangan, dan penjualan (Hermawan, 2012).

Berdasarkan hal tersebut, kehadiran brand hijab Aisar.Scarf dalam pemasaran industri melalui internet telah mengundang banyak perusahaan online untuk menawarkan diri sebagai mitra bisnis. Hal ini mendorong perusahaan untuk melakukan berbagai pertimbangan penerimaan konsumen sebagai mitra bisnis. Karena selain menjual produk Aisar.Scarf, mitra bisnis harus bisa menjaga citra publik yang baik bagi perusahaan. Hal ini disebabkan oleh fakta bahwa mitra bisnis, juga dikenal sebagai pengecer resmi, dianggap sebagai bagian dari tenaga kerja pemasaran jika mereka memiliki perjanjian hukum yang diperlukan.

Aisar.Scarf memasarkan melalui reseller resmi yang merupakan salah satu implementasi dari sistem pemasaran vertikal. Hal ini sesuai dengan definisi Kotler dan Armstrong (1997) tentang sistem pemasaran vertikal (SPV atau VMS = Vertical Marketing System), yaitu saluran distribusi yang dibangun sebagai sistem yang terintegrasi oleh produsen, distributor, dan pengecer. Dimana sistem pemasaran yang terbentuk ini dipegang oleh sesuatu (anggota) orang lain karena ada kontrak yang memungkinkan mereka untuk berkolaborasi.

Menurut Kotler dan Armstrong (1997) sistem pemasaran vertikal dapat didominasi oleh para pelaku sistem tersebut, yaitu produsen, pedagang besar dan pengecer. Ada sistem pemasaran vertikal untuk mengontrol perilaku saluran dan mengelola konflik. Penghematan dapat dicapai melalui ukuran besar, kekuatan tawarmenawar dan penghapusan paritas layanan.

Maka berdasarkan hal itu dealer resmi Aisar.Scarf memiliki banyak fitur termasuk penetapan harga produk, segmentasi pemasaran lanjutan, kualitas layanan, dll., asalkan tidak melanggar banyak ketentuan perjanjian tertulis.

Penggunaan media internet yang sudah dilakukan oleh Aisar.Scarf melalui digital marketing telah memberikan informasi kepada berbagai kalangan di perusahaan tentang penilaian sebuah brand hijab modern. Menurut hasil penelitian, informasi tentang merek Aisar.Scarf telah tersampaikan dengan baik kepada pelapor dua kategori wanita Muslim yang berbeda sebagai pengguna internet aktif. Namun, penyebaran informasi yang tidak sepenuhnya lengkap, karena ada sumber dalam kategori muslim seperti pengguna hijab modern (bukan konsumen Aisar.Scar) yang tidak mengenal Aisar.Scarf sebagai brand hijab. Berbeda dengan sumber dalam kategori muslim seperti pemakai hijab (konsumen Aisar.Scarf) yang mengenal Aisar.Scarf sebagai brand hijab. Juga ada sumber yang tidak mengetahui keberadaan akun Aisar.Scarf di berbagai media sosial internet. Hal ini disebabkan karena penyebaran informasi yang kurang lengkap kepada pelapor baik kategori wanita muslimah sebagai pengguna internet aktif. 


\section{Vol 3 No 3 (2022) 466-483 P-ISSN 2620-295 E-ISSN 2747-0490 DOI:_1047467/elmal.v3i3.930}

Menurut Swasti (2016), merek yang berperan sebagai indikator kualitas dapat membentuk nilai dan sifat suatu produk sedemikian rupa sehingga melekat di benak konsumen. Merek dapat membuat konsumen sadar akan keuntungan dan manfaat membeli sebuah merek. Hal ini dapat membuat konsumen tetap berbelanja selama merek lain hanya menjadi bukti janji kepada konsumen bahwa mereka telah setia menggunakan merek tersebut.

Atas dasar ini, Instagram telah membawa pengenalan merek kepada konsumennya melalui pemasaran digital melalui jejaring sosial, bagi Aisar.Scarf. Hal ini terlihat dari jumlah followers Instagram yang terus meningkat hingga saat ini. Selanjutnya, ketika item baru dipublikasikan di Instagram, semakin banyak pelanggan e-commerce, seperti Shopee dan Tokopedia, yang akan memesan dan membelinya.

Swasty (2016) berpendapat bahwa pentingnya sebuah merek bagi konsumen peranan yang sangat penting bagi perusahaan sebagai pemilik merek. Dimana sebuah merek yang berfungsi sebagai pengidentifikasi atribut produk dapat membedakannya dengan produk pesaing sejenis. Meskipun proses produksi dan desain produk yang mudah ditiru dan diduplikasi, pengalaman produk yang menyatu di benak konsumen versus aktivitas pemasaran tidak akan mudah ditiru atau hilang di benak konsumen. Ini seperti berbagai brand fashion hijab syar'i yang tersebar di seluruh Indonesia yang memiliki berbagai produk serupa dengan Aisar.Scarf tidak sedikit pemasaran dilakukan dengan cara yang sama.

Digital marketing dari Aisar.Scarf sebagai brand fashion hijab modern di media marketing. Menurut hasil penelitian ini, itu adalah salah satu metode pemasaran yang paling efektif. Menggunakan berbagai media pemasaran digital seperti media sosial dan e-commerce seperti Instagram, Tiktok, Shopee dan Tokopedia, media tersebut relevan saat ini. Hal ini disebabkan perkembangan global yang memasuki era digital dalam perjalanan Revolusi Industri 5.0, di mana penggunaan berbagai media internet khususnya di Indonesia berlangsung sepenuhnya dari dalam masyarakat.

Pemanfaatan digital marketing oleh Aisar.Scarf tidak hanya sebagai media pemasaran, tetapi juga dapat menciptakan brand awareness di masyarakat sebagai brand modern dengan kerudung yang mewah. Dilihat dari hasil penelitian yang menunjukkan bahwa jejaring sosial Instagram merupakan salah satu saluran pemasaran digital Aisar.Scarf yang berperan aktif sebagai perantara pemasaran. Ini tentang pemasaran yang ditargetkan. Departemen pemasaran ditujukan untuk wanita Muslim sebagai fashionista dan pengguna internet aktif.

Dilihat dari perilaku konsumen seperti peminat fashion dan pengguna internet aktif. Konsumen sebagai peminat fashion selalu mencari model atau brand fashion yang sesuai dengan seleranya. Penggemar fashion bisa menjadi pengguna internet yang aktif. 


\section{Vol 3 No 3 (2022) 466-483 P-ISSN 2620-295 E-ISSN 2747-0490 DOI:_1047467/elmal.v3i3.930}

Karena para pecinta fashion banyak mendapatkan informasi di internet tentang model atau brand yang sesuai dengan selera mereka atau bahkan menjadi sumber inspirasi baru selera mereka di dunia fashion.

Sebagai pengguna internet yang aktif, tentunya para pecinta fashion akan memilih media yang tepat sebagai pencari informasi dan sebagai sarana eksplorasi di bidang fashion. Menurut hasil penelitian, jejaring sosial Instagram merupakan salah satu sarana yang tepat untuk digunakan. Melihat berbagai fasilitas yang ditawarkan Instagram cukup untuk menutupi kebutuhan tersebut. Hal ini terlihat dari banyaknya followers di akun media sosial Aisar.Scarf di Instagram yang sebagian besar memiliki ribuan followers di akunnya.

Juga, akun pengikut yang berbeda (followers) dan yang diikuti (following) adalah akun yang memiliki passion yang sama terhadap fashion. Sedangkan unggahan yang dilakukan oleh para pecinta fashion merupakan hasil foto dan video terbaik yang memiliki nilai seni tinggi di dunia Mode. Berdasarkan hal tersebut, pemasaran yang dilakukan oleh Aisar.Scarf melalui peran aktifnya di jejaring sosial Instagram telah mencapai segmentasi yang tepat, meskipun tidak memanfaatkan struktur layanan promosi yang terdapat di dalamnya. Hal ini terlihat dari semakin banyaknya konsumen dan pesanan yang selalu diperebutkan konsumen menurut sumber 1 dan 2 . Melihat hal tersebut, digital marketing melalui media sosial Instagram telah menciptakan awareness terhadap brand Aisar.

Maka dari itu, untuk pemasaran melalui semua akun pemasaran digital Aisar.Scarf harus dibuat sesuai dengan fungsi yang relevan seperti meningkatkan penjualan dan meningkatkan kesadaran merek untuk berbagai perusahaan sebagai merek jilbab. Namun hal tersebut tidak memungkinkan karena keterbatasan tenaga kerja yang menjadi kendala utama.

\section{KESIMPULAN}

Berdasarkan hasil penelitian, peran pemasaran digital Aisar.Scarf sebagai merek jilbab adalah sarana pemasaran yang dilakukan melalui media internet. Pemasaran Digital Aisar.Scarf, yang mencakup perdagangan elektronik, yaitu; Shopee dan Tokopedia dan Jejaring Sosial; Instagram dan Tiktok. Jangan lupa ini adalah jenis jejaring sosial yang memainkan peran aktif dalam melaksanakan kegiatan pemasaran. Instagram salah satu media sosial yang memainkan peran aktif menjadi sarana pemasaran langsung, perannya menyerupai katalog, tetapi secara online. Sementara Eccomerce berperan dalam memeriksa atau berharap lebih detail tentang jilbab yang diinginkan, dan Anda dapat melihat ulasan teman atau orang lain yang memiliki (pernah) membeli jilbab di Aisar.Scarf. 


\section{Vol 3 No 3 (2022) 466-483 P-ISSN 2620-295 E-ISSN 2747-0490 DOI:_1047467/elmal.v3i3.930}

Strategi menggunakan media online yang dilakukan oleh Aisar.Scarf dengan menyediakan layanan maksimal kepada konsumen menyediakan informasi produk digital dalam produk-produk nyata (foto asli) yang meluas melalui jejaring sosial, intraments dan Tiktok. Selain memformat informasi, pembelian, iklan, layanan dan informasi pemasaran promosi, semua telah disajikan dalam bentuk digital.

Kegiatan pemasaran dilakukan dengan Aisar.Scarf melalui jejaring sosial Instagram, penyebaran informasi belum sepenuhnya memenuhi semua pengguna internet aktif. Itu terlihat dari hasil penelitian untuk narasumber, ada beberapa yang belum tahu untuk Aisar.Scarf sebagai merek jilbab. Namun, hasil investigasi menunjukkan bahwa pemasaran yang dilakukan oleh Aisar.Scarf melalui pemasaran digital telah memberikan dampak serta kontribusi dan efek positif atas penjualan produk. Hal tersebut bisa dilihat pada jumlah konsumen yang bertambah serta berkomunikasi dengan Aisar.Scarf melalui Instagram dan juga Shopee.

\section{DAFTAR PUSTAKA}

Aaker, D A. (2012). Manajemen Ekuitas Merek: Memanfaatkan Nilai dari Suatu Merek. Jakarta: Mitra Utama. Spektrum.

Aaker, D A. (2013). Manajemen Pemasaran Strategis. Edisi Ke-8. Jakarta: Salemba Empat.

Adisaputro, G. (2010). Manajemen Pemasaran Analisis untuk Perancangan Strategi Pemasaran. Yogyakarta: UPP STIM YKPN.

Arifianto, S. (2018). Praktik Budaya Media Digital Dan Pengaruhnya. Yogyakarta. Aswaja Pressindo.

Baroroh, U., Cahyo, N. H. W., Afifah, N.G. (2017). Strategi Komunikasi Hijabers Semarang dalam Mensyiarkan Hijab pada Muslimah Muda di Semarang. Jurnal Komunikasi dan Penyiaran Islam. Semarang. UIN Walisongo Semarang.

Berlo, K. David. (1960). The Process of Communication: An Introduction to Theory and Practice. New York: Holt, Rinehart and Winston.

Bungin, B. (2001). Metodologi Penelitian Komunikasi. Jakarta: PT. Rajagrafindo Persada.

Chaffey, D \& PR Smith. (2008). Marketing Excellence: Planning and Optimizing Your Digital Marketing. UK: Butterworth-Heinemann. 


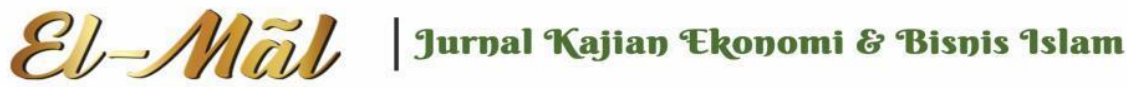

\section{Vol 3 No 3 (2022) 466-483 P-ISSN 2620-295 E-ISSN 2747-0490 DOI:_1047467/elmal.v3i3.930}

Creswell, J.W. (2014). Research Design; Qualitative, Quantitative and Mixed Methods Aprroaches. University Of Nebraska-Lincoln. Sage Publications, Inc. 2455 Teller Road, Thousand Oaks, California 91320.

Daymon, C. \& Holloway, I. (2011). Qualitative Research Methods in Public Relations and Marketing Communications. Second Edition. USA and Canada. Routledge 2 Park Square, Milton Park, Abingdon, Oxon OX14 ARN.

Effendi, M. (2010). Peranan Internet Sebagai Media Komunikasi. Jurnal Dakwah dan Komunikasi. Vol. 4 No. 1 pp. 130- 142.

Flew, T. (2014). New Media 4th Edition. Oxford University Press. Australia.

Folkerts, J., Lacy S., Larabee A. (2008). The Media in Your Life: An Introduction to Mass Communication (4th ed.) Boston: Pearson Cavazza, F. Education Inc.

Hermawan, A. (2012). Komunikasi Pemasaran. Jakarta: Erlangga.

Humanika Moriarty, S., Mitchell, N \& Wells, W. (2011). Advertising Principles \& Practice edisi ke-8. Jakarta: Kencana.

Irwansyah. (2017). Komunikasi Bisnis. Jakarta: Mitra Wacana Media.

Iskandar. (2009). Metodologi Penelitian Kualitatif: Aplikasi untuk Penelitian Pendidikan, Hukum, Ekonomi dan Manajemen, Sosial, Humaniora, Politik, Agama dan Filsafat. Jakarta. Gaung Persada Press.

Keller, K. L. (2003). Strategic Brand Management: Building, Measuring and Managing Brand Equity, 2 nd Edition. Upper Saddle River (N.J.). Pearson Prentice Hall.

Kotler, P \& Amstrong, G. (2004). Dasar-dasar Pemasaran. Jakarta: Indeks.

Kotler, P \& Armstrong, G. (2008). Prinsip - Prinsip Pemasaran. Jilid 2, Edisi 12. Jakarta: Erlangga.

Kotler, P \& Armstrong, G; Alih Bahasa Alexander Sindoro dan Benyamin Molan. (1997). Dasar-Dasar Pemasaran. Jilid 2. Jakarta: Prenhalindo

Kriyantono, R. (2012). Public Relations Writing: Teknik Produksi, Media Public Relations dan Korporat. Edisi Kedua. Jakarta. Prenadamedia Group.

Kriyantono, R. (2014). Teknik Praktis Riset Komunikasi. Jakarta: Prenadamedia Group.

Kriyantono, R. (2015). Public Relations, Issue \& Crisis Management. Pendekatan Critical Public Relations, Etnografi Kritis dan Kualitatif. Jakarta: Prenadamedia Group. 


\section{Vol 3 No 3 (2022) 466-483 P-ISSN 2620-295 E-ISSN 2747-0490 DOI:_1047467/elmal.v3i3.930}

Kurnia, Septiawan S. (2005). Jurnalisme Kontemporer. Jakarta: Yayasan Obor Indonesia 135-136.

Kusumastuti, Y. I. (2009). Komunikasi Bisnis: Membangun Hubungan Baik dan Kredibilitas. Bogor: IPB Press.

Mc Quail, D. (2011). Teori Komunikasi Massa. Jakarta: Salemba

Moleong, L. J. (2010). Metodologi Penelitian Kualitatif. Bandung: PT. Remaja Rosda Karya.

Mulyana, D dan Solatun. (2008). Metode Penelitian Komunikasi. Bandung: PT. Remaja Rosdakarya Offset.

Mursito, BM. (2006). Memahami Institusi Media. Sebuah Pengantar. Surakarta: Lindu Pustaka.

Nadya. (2016). Peran Digital Marketing Dalam Eksistensi Bisnis Kuliner Seblak Jeletet Murni. Jurnal Riset Manajemen dan Bisnis. JRMB. Vol. 1, No. 2. 133-144. ISSN 2527-7502. Fakultas Ekonomi Universitas Islam Attahiriyah.

Neuman, W. L. (2014). Social Research Methods: Qualitative and Quantitative Approaches. New York: Pearson.

Noegroho, H. (2010). Pemanfaatan Teknologi Komunikasi Sebagai Media Instruksional. Kasus pada Portal Pembelajaran e-dukasi.net bagi Siswa dan Guru di SMA Negeri 5 Bogor. Tesis. Magister Ilmu Komunikasi, Fakultas Ilmu Sosial dan Ilmu Politik, Universitas Muhammadiyah Jakarta.

Nursatyo, Dini R. (2018). Strategi Komunikasi Pemasaran Digital Situs Pembanding Harga Telunjuk.com. Jurnal Ilmu Komunikasi Expose Vol. 1 No. 2.

Oktaviani, Femi dan Rustandi, D. (2018). Implementasi Digital Marketing dalam Membangun Brand Awareness. Jurnal Profesi Humas Vol. 3 No. 1. Universitas BSI. Bandung.

Putri, S.D. dan Fithrah, D. S. (2017). Pengaruh Online Marketing Campaign \#samyangchallange terhadap Consumer Behavior Digital Natives Pengguna Youtube Indonesia. Jurnal Profesi Humas, 1 (2), 132-141.

Priyatna, S. dan Ardianto. E. (2008). Tujuh Pilar Strategi Komunikasi Bisnis. Bandung: Widya Padjadjaran.

Prisgunanto, I. (2006). Komunikasi Pemasaran: Strategi dan Taktik. Bogor: Ghalia Indonesia. 


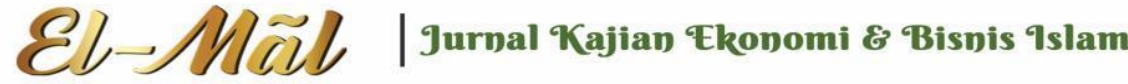

\section{Vol 3 No 3 (2022) 466-483 P-ISSN 2620-295 E-ISSN 2747-0490 DOI:_1047467/elmal.v3i3.930}

Ruslan, R. (2008). Metodologi Penelitian Public Relations dan Komunikasi. Jakarta: PT. Raja Grafindo Persada. Severin,

W. J., Tankard dan James W. (2005). Teori Komunikasi: Sejarah, Metode dan Terapan di dalam Media Massa. Jakarta: Predana Media.

Shimp, T. A. (2014). Komunikasi Pemasaran Terpadu dalam Periklanan dan Promosi. Jakarta: Salembat Empat. Sujarweni,

V. W. (2014). Metode Penelitian: Lengkap, Praktis dan Mudah Dipahami. Yogyakarta: Pustaka Baru Press.

Swasty, W. (2016). Branding: Memahami dan Merancang Strategi Merek. Bandung: PT. Remaja Rosdakarya.

Tasruddin, R. (2011). Strategi Periklanan dalam Perspektif Komunikasi Pemasaran. Makassar: Alauddin University Press.

Tjiptono, F. (2001). Strategi Pemasaran. Yogyakarta: Andi Offset.

Vivan, J. (2008). Teori Komunikasi. Jakarta: Kencana 